\title{
Extinction in transition: coca, coal, and the production of enmity in Colombia's post-peace accords environment
}

\author{
Hannah Meszaros Martin ${ }^{1}$ \\ Oscar Pedraza \\ Goldsmiths, University of London, UK \\ Bard College, USA
}

\begin{abstract}
At the Paris Climate Summit in 2015, then Colombian president Juan Manuel Santos proposed constructing a multi-national biodiversity corridor that would extend from the Andes to the Brazilian Atlantic coast. Santos highlighted increased militarization of the territory as one advantage of the corridor. In this model, ecological conservation becomes a matter of national/natural security, in the form of counterinsurgency to counter illegal economies. Climate change and ecological disaster mean the forest needs the military power of the State to save it from destruction. We argue that such conservation entails a form of necropolitics lying in wait; because to conserve one part is to condemn the other - framed as the enemy - to certain destruction, as land is simultaneously designated for large-scale development projects. Conservation, in effect, becomes tied to a form of extinction. Our article examines two increasingly militarized frontiers that work through conservation in Colombia. The first is where the Andes meets the Amazon rainforest, an area that has seen an increase in deforestation following the 2016 Peace Agreement with the FARC. Deforestation is often attributed to the cultivation of coca (used to produce cocaine), and the solution posited by the government is to eradicate the plant. We argue that eradication of illicit crops is a form of enforced extinction that militarizes the forest, targeting both human and non-human inhabitants. The second frontier concerns coal mining on the Caribbean coast, where mass environmental devastation induced by the industry has led to a forced reorganization of life in the region. The military guards the sites of extraction and those who oppose coal mining become targets for elimination. We bring these two cases - coal and coca - into dialogue, to trace the extinction-driven expansion of extractive economies, a process intertwined with armed conflict, narcotrafficking, and now, with transitional politics.
\end{abstract}

Keywords: Necropolitics, transitional justice, conservation, militarization, Colombia, counterinsurgency

\section{Résumé}

Lors du sommet de Paris sur le climat en 2015, Juan Manuel Santos, alors président colombien, a proposé de construire un corridor de biodiversité multinational qui s'étendrait des Andes à la côte atlantique brésilienne. Santos a mis en avant la militarisation accrue du territoire comme l'un des avantages de ce corridor. Dans ce modèle, la conservation écologique devient une question de sécurité nationale/naturelle, sous forme de contreinsurrection pour lutter contre les économies illégales. Le changement climatique et le désastre écologique signifient que la forêt a besoin de la puissance militaire de l'État pour la sauver de la destruction. Nous

\footnotetext{
${ }^{1}$ Dr. Hannah Meszaros Martin, Advanced Researcher, Forensic Architecture, Goldsmiths, University of London, UK. Email: hannahjmm "at" gmail.com. Dr. Oscar Pedraza, Fellow, Center for Human Rights and the Arts, Bard College, USA. Email: oscarpedra "at" gmail.com. We would like to thank the editors and peer reviewers for all of your input during the process of writing this article, as well as all the participants of the Crisis Conservation workshop held from 5-9 October 2020, whose feedback was invaluable. The workshop was made possible by an NWO-VIDI grant (nr. 425-14-001). Our own collaboration began in Tierra Digna in 2017, we thank them for enabling this work. We also thank our advisors at the CUNY Grad Center and the Centre for Research Architecture and Forensic Architecture who supported this work throughout our PhDs. This is the second article in Bram Büscher (ed.). 2021. "Political ecologies of extinction", Special Section of the Journal of Political Ecology 28: 696-888.
} 
soutenons qu'une telle conservation implique une forme de nécropolitique à l'affût. La conservation d'un élément en condamne un autre - présenté comme l'ennemi - à une destruction certaine, puisque des terres sont simultanément désignées pour des projets de développement à grande échelle. La conservation, en effet, devient liée à une forme d'extinction. Notre article examine deux frontières de plus en plus militarisées qui fonctionnent à travers la conservation en Colombie. La première est celle où les Andes rencontrent la forêt amazonienne, une zone qui a connu une augmentation de la déforestation suite à l'accord de paix de 2016 avec les FARC. La déforestation est souvent attribuée à la culture de la coca (utilisée pour produire de la cocaïne), et la solution proposée par le gouvernement est d'éradiquer cette plante. Nous soutenons que l'éradication des cultures illicites est une forme d'extinction forcée qui militarise la forêt, en ciblant les habitants humains et non humains. La deuxième frontière concerne l'exploitation du charbon sur la côte caraïbe, où la dévastation environnementale massive induite par l'industrie a conduit à une réorganisation forcée de la vie dans la région. L'armée garde les sites d'extraction et ceux qui s'opposent à l'exploitation du charbon deviennent des cibles à éliminer. Nous faisons dialoguer ces deux cas - le charbon et la coca - afin de retracer l'expansion des économies extractives due à l'extinction, un processus entrelacé avec les conflits armés, le narcotrafic et, maintenant, avec les politiques de transition.

Mots-clés: Nécropolitique, justice transitionnelle, conservation, militarisation, Colombie, contre-insurrection

\section{Resumen}

En la conferencia sobre el cambio climático de 2015, el entonces presidente de Colombia, Juan Manuel Santos, propuso la construcción de un corredor de biodiversidad multinacional que se extendería desde los Andes hasta la costa atlántica de Brasil. Como una de las ventajas de este corredor, Santos resaltó la militarización del territorio. En ese modelo, la conservación toma la forma de la contrainsurgencia. En tiempos de cambio climático y desastres ecológicos, la selva requiere el poder militar del estado para salvarla de su destrucción, que es usualmente presentada como responsabilidad de las economías ilegales. La conservación ecológica se vuelve entonces un asunto de seguridad nacional/natural. Argumentamos que esa conservación implica una forma de la necropolítica que descansa al acecho; conservar un lugar condena a otro -definido como enemigoa ser destruído, pues mientras un lugar es protegido otros se vuelven objeto de grandes proyectos extractivos y de desarrollo. La conservación por lo tanto se encuentra ligada a la extinción. Este artículo examina dos fronteras militarizadas que operan a través de la conservación en Colombia. La primera se encuentra en el lugar en el que se conectan los Andes y la selva Amazónica, un área que ha vivido una creciente deforestación desde la firma de los acuerdos de paz en 2016 entre el estado y las FARC. La deforestación es generalmente atribuída al cultivo de coca (que se usa para prooducir cocaína), por lo que la solución gubernamental es erradicar la planta. Argumentamos que la erradicación de plantas ilicitas es una forma de extinción forzada que lleva a la militarizacíón de la selva y a convertir en objetivos militares tanto a humanos como a no humanos. La segunda frontera se refiere a la extracción de carbón en la costa caribe del país, donde la devastación ambiental masiva, producto de la industria extractiva ha llevado a la reorganización de la vida de la región. Las fuerzas militares del estado protegen las minas y su infraestructura, haciendo que quienes se oponen al carbón se conviertan en objetivos de eliminación o neutralización. En el artículo realizamos un díalogo entre ambos casos -coca y carbón- para analizar la expansión de las economías extractivas impulsadas por la extinción, un proceso que además se mezcla con la guerra, el narcotráfico y ahora, las políticas de la transición.

Palabras clave: Necropolítica, justicia transicional, conservación, militarización, Colombia, contrainsurgencia, extractivismo, coca, coal.

\section{Introduction: the context of the peace accords}

In 2016, the government of Juan Manuel Santos signed the peace accords with the Fuerzas Armadas Revolucionarias de Colombia (FARC), the oldest guerrilla movement on the continent. In accordance with international tradition, the Colombian government established a Transitional Justice System. ${ }^{2}$ However, in a referendum held that same year, a vote against the result of the peace accords prevailed, and with it, the

\footnotetext{
2 The Sistema Integral de Verdad, Justicia y Reparación y no Repeticiòn (SIVJRR) has three main institutions: a Truth Commission, an Alternative Justice System (JEP) and a Search Unit of Disappeared People (Unidad de Busqueda).
} 
legitimacy of the transitional system was put in question, as well as many of the agreements designed to end a war that has lasted more than half a century.

This was not Colombia's only peace process. Eleven years earlier, in 2005, the government of Alvaro Uribe Vélez initiated a much-criticized peace process with paramilitary groups united under the name of Autodefensas Unidas de Colombia (AUC). It was during this peace agreement that Colombia began a discussion about transitional justice scenarios, victimhood, reparations and non-repetition.

Transitional justice is generally defined in a teleological manner, organized as a progressive sequence, beginning from a moment of chaos and war, followed by a transition and its subsequent resolution into liberal democracy and a strong market economy (Bowsher 2018; Castillejo 2017; Grandin 2011; Rothberg 2012). In the case of Colombia, transitional justice processes have not followed this sequence. The 2005 process did not end the war, as paramilitarism was not fully dismantled and guerrilla groups like the FARC and the Ejército de Liberación Nacional (ELN) remained active. Likewise, the 2016 peace accords did not include the ELN, and today, different irregular armies are thriving across the country. ${ }^{3}$ Hence the promises, institutions, discourses and practices of transitional justice coexist with different iterations of war, leading to overlapping transitional justice processes and multiple formations of armed violence.

Nevertheless, the idea of strengthening market economies, including via transnational investment, remained solid throughout both peace processes. Santos made it clear from the outset of the peace negotiations with the FARC that Colombia's 'economic model' was to be left out of the discussion. By excluding the 'economic model', Santos meant two things: first, that the existing neoliberal arrangements, foreign investments and market relations were to remain intact; and second, that Colombia's extractivist industries and the use of nature as a resource for capitalist accumulation was not up for debate. ${ }^{4}$

In this article, we focus on what these scenarios mean for relations between environmental conservation and militarization. Central to this analysis is a discussion of violence and conceptions of nature. We argue that the peace processes' narrow definition of violence - anthropocentric in conception - renders environmental violence in the context of war invisible. This definition of violence is at the center of the practices and discourses in which a future of 'peace' is conceived. The negation of environmental violence in turn informs processes of justice, reparations and reconciliation, leaving those who might have experienced these forms of violence without recognition or legal recourse. Additionally, within conceptions of nature and transitional justice we witness the Colombian state continuously reifying nature as an economic resource, reinforced by processes of militarization and public policymaking that decide what is worthy of conservation and what should be left to die and go extinct, a process we conceptualize as 'necropolitics' (Mbembe 2003).

To articulate these points, we bring together two economic activities not usually viewed together. One is the coal industry, located in northern Colombia, near the Caribbean coast. Coal mining represents a mostly legal, large-scale regulated economy which in the first trimester of 2019 accounted for 68\% of the mining sector and represented $1.18 \%$ of Colombian GDP. ${ }^{5}$ The other is the illicit cultivation of coca (Erythroxylum coca), used to produce cocaine. While coca cultivation has been relatively widespread throughout the country - present in twenty-two departments out of thirty-two - historically coca has been highly concentrated in the south, along the border with Ecuador. ${ }^{6}$

\footnotetext{
${ }^{3}$ The demobilization of AUC did not mean paramilitarism disappeared, since multiple groups remained active throughout the country. Likewise, the demobilization of FARC was not complete and dissident factions continued in armed confrontation. Although these groups are not the same as their predecessors, they have increased their power and have contributed to the escalation of war.

${ }^{4}$ See Hannah Meszaros Martin (2016), 'How to make peace with the forest: Development and war in Colombia',_Open Democracy https://www. opendemocracy.net/ hannah-meszaros-martin/ how-to-make-peace-with- forest-developmentand- war-in-colombia [accessed 28 Dec. 2021].

5 Análisis del Comportamiento del PIB Minero Primer Semestre 2019, Ministerio de Minas y Energía de Colombia: https://www.minenergia.gov.co/documents/10192/24089918/PIB+I+triemestre+2019.pdf/79b1f2d2-c16d-48df-91d155bf7ec13cb3 [accesed 28 Dec. 2021]

${ }^{6}$ While cultivation density and prevalence can fluctuate over time, and in very rare circumstances there can be no production at all, cultivation in each department has remained relatively stable. In general, the number of departments with
} 
Coca and coal are seen as substantially different worlds in Colombia. In this article, we create a counterpoint (Ortiz 1995) between these two human-environmental arrangements, as they produce specific state formations, modes of violence, and ways to assert life and death in a context of political transition marked by uncertainty.

We argue that coal and coca work in a necessary tandem of extinction and conservation. The coal industry has irrevocably transformed the landscape through historical environmental and political violence, resulting in a geography in which certain human and non-human modes of life are continuously at risk of expulsion and extinction. In the case of coca, we look at how the eradication of this outlawed plant shapes and informs patterns of extinction and salvation in the Amazon. For governmental institutions, practices and discourses, the cultivation of coca is presented not only as a threat to the survival of delicate ecosystems, but also as a threat to the very concept of peace. Coca's enforced extinction via eradication is justified in order to supposedly 'conserve' the rapidly disappearing forest - a disappearance which is considered a threat to national security.

In the counterpoint between coal and coca, we witness a direct link between forms of destruction and conservation. With coca, there is an idea that conservation via eradication of the plant would uphold peace, and with coal, that more extraction (entailing an eradication of other forms of life to make way for mining and associated infrastructure) would also secure a more peaceful future. In these two examples, eradication is tied to the idea of conservation and produces a very specific condition: the militarization of nature and the production of enmity. What mediates these two seemingly opposite forces, we argue, is increased militarization on the ground, which escalates violence and continues the conflict that supposedly ended in 2016.

We begin the article with a discussion of the concept of necropolitics and its mediation between conservation and extinction, or life and death. We then outline how we understand the terms nature and violence, and why they are central to discussions of transitional justice and its broader effects. Then we turn to an examination of each case study: coca and coal. We highlight which aspects of each have gone unrecognized and been negated in the definitions and discussions of violence throughout the Colombian war. We tell the story of how each economy unfolded in the environment, and how this environment became the medium and mode through which violence was perpetuated.

\section{The necropolitics of human and nonhuman life}

Our conceptualization of necropolitics is twofold. First, as the enmity that shapes and informs modes of environmental violence. Perceptions of the enemy and the environment are merged here, and by being bound together, following the figure of Homo Sacer (Agamben 1995), produce a subject that can be killed with impunity. ${ }^{7}$ This method of constructing violence as sewn into the very pathways of the natural world was visible during the Cold War (Hamblin 2013). When Cold War planners designed violence intended to eliminate the enemy as a categorical entirety - in that case 'communism' - they included the environments in which this enemy lived (and where it reproduced itself). Our second conceptualization of necropolitics is one that lies in wait in patterns of conservation and resource extraction, shaping the future of extinction in diverse and fragile ecosystems.

In his elaboration of necropolitics, Mbembe argues that the sovereign's right to wage war is followed by the right to kill. This notion of war goes beyond the boundaries of physical confrontational violence, extending itself to the routinized practices that administrate life, namely, the biopolitical dimension of the exercise of power (Foucault 2003). Foucault extends this idea to oppose the longstanding assumption that war is embodied by disorder and savagery, whereas peace is defined through order and the proper administration of social relations. For Foucault, "law is not pacification, for beneath the law, war continues to rage in all mechanisms of power, even the most regular. War is the motor behind the institutions of power" $(2003,50)$.

coca fluctuates between 21-25. http://www.odc.gov.co/sidco/oferta/cultivos-ilicitos/departamento-municipio [accessed Dec. 28 2021]

${ }^{7}$ Agamben uses the figure of the Homo Sacer, which he argues is the representation of bare life - the exception that is derived from exclusion - to establish the preconditions of sovereignty. 
Following Mbembe, the state - defined as a sovereign power within specific geographical limits - can suspend the judicial order in areas considered as disordered and savage, to enforce its rule through violence "in the service of civilization." Mbembe gives the example of European rule over colonial territory to demonstrate this form of governance and violence. The sovereign rule of the colonizer is a constant state of exception, beyond a formal condition of war. In this account, the creation of enmity is crucial, as the enemy becomes the repository of that which is defined as a threat to particular modes of life, and thus not only establishes what needs to be killed, but also what needs to be protected: "to be deprived of an enemy means being deprived of the kind of relation of hatred that authorizes the giving of a free rein to all sorts of otherwise forbidden desires" (Mbembe 2019, 48).

However, when Agamben and Mbembe describe 'the enemy', they are strictly referring to humans. Here, we extend the category of 'the enemy' and the possibility of being 'killed with impunity' beyond the human to potentially encompass the Earth as a whole (Martin 2019). If biopolitical power expands its reach to include plants, animals and bacteria, these lifeforms are in turn exposed to the necropolitical, the power that determines the destruction, and ultimately the death of its subjects.

Many scholars have highlighted the uses of counterinsurgency practices and discourses for conservation purposes (Bhan \& Trisal 2017; Dutta 2020). These analyses highlight how military operations are articulated through the protection of the environment - often referred to as green militarization (Lunstrum 2014). These novel practices of military deployment are oriented towards the strong assertion of sovereign state power and the protection of endangered forms of life (Annecke \& Masubelele 2016; Büscher \& Fletcher 2018; Marijnen 2017). Scholars have shown how the protection of nature is tied to the securitization and surveillance objectives of nation-states, which in turn create forms of enmity that are instrumental to the militarization of the landscape (Fletcher 2018; Peluso \& Vandergeest 2011; Lunstrum 2015). This article expands these analyses in two ways: first, by considering the ways in which the notion of the enemy includes not only humans, but also specific forms of nature and socionatural arrangements; second, by examining the necropolitical practices and discourses that these definitions of enmity create amid transitional justice, and the practices of conservation and extinction they render possible.

As transitional justice seeks to define the past of violence and the future of peace, the assemblages of coca and coal produce different expectations of the future through the notion of enmity. Therefore, different practices of conservation and extinction are articulated around coal and coca. In the case of coal, the idea of the enemy was historically composed around those who were considered to 'oppose' the industry, namely campesino organizations, unions, and indigenous communities. Later, with the introduction of transitional justice, these same groups were posited as a threat to a future of stability, and to the legal regulation of natural resource extraction and the projects of conservation and land recovery conducted by mining corporations.

Coca, however, has always been framed as an enemy of the state. This did not change during the peace negotiations. In fact, throughout the negotiations, illicit crops - coca, poppy and marijuana - were continuously framed as an 'enemy of peace.' As the opposite of 'illicit', 'peace' was defined according to the successful realization of legal forms of economic development that would drive Colombia away from a past which was violent because of the dominance of illegal industries. On the other side of the coin, government institutions, politicians and mining conglomerates perpetuate the idea that coal extraction is an exemplary legal, regulated and accountable activity. Thus, the coal industry is presented publicly as the future to aspire towards for extractivist industries.

Coca and coal are placed on opposite ends of the legal spectrum in the practices, discourses and institutions of the state. The coal industry is dislocated from the present condition of war and transitional scenarios, situating its conflicts in the past within the linearity of the historization of armed violence. Simultaneously, coal extraction is deemed an exemplary use-of-nature-as-resource in a 'peaceful' future with a legally regulated stable market economy situated in liberal frameworks of operation. On the other hand, coca increasingly defines the present condition of war in the country; the plant that continues to fuel violence and illegality. For transitional politics, coca is the anti-future, a form of life that must be eradicated, and even made extinct, in order for the country to enter into 'peace' and thrive with legality, a stable democracy and strong markets. 
Finally, we highlight the interactions that coal and coca have had with the war that went unrecognized as violence and thus, fall outside the transitional justice system. When coca and coal materialize themselves through (the lived experience of) violence, they do so via the environments they occupy. In both cases, we witness forms of enforced extinction, which are the result of the eradication of forms of life that are seen to be exterior (or contradictory) to the logics of the accumulation of capital.

\section{Expulsions of nature and violence}

Studies of transitional justice scenarios often take for granted the formation of notions of violence, environment and nature, in order to study and evaluate the practical uses of the environment in the aftermath of war (Conka \& Dabelko 2002; Mathew, Brown \& Jensen 2009; Ide 2019). Similarly, transitional justice institutions mostly fail to recognize the active role of the environment in war or disregard its role in a future beyond war.

When nature appears in the discussions of the longstanding war in Colombia, it is fundamentally defined by its subordination: it exists to serve the material desires of humanity. The environment therefore appears as a raw material to be transformed into a commodity through labor, existing in relation to war when it can be explicitly tied to the instrumental interests of economic activity. ${ }^{8}$

Our understanding of violence takes a relational approach that places the human-in-nature (Moore 2015). Definitions of environmental violence sometimes envision a human act inflicted upon a passive and objectified nature. What we are suggesting is not to qualify the 'type' of violence, as this comes with its own set of problems, and can reinforce the dualisms we seek to break down. We are looking instead at violencevia-environment, when violence is not only conducted environmentally, but the environment itself becomes the mode and medium of violence.

Colombia's longstanding war has been defined as 'armed conflict.' This definition is an attempt to situate the historicity of war within standard frameworks of war regulations, especially International Humanitarian Law (Valencia 1990; Human Rights Watch 1998; Bradley 2013). In that regard, violence is equated with armed conflict, and it is armed conflict as such that transitional justice institutions, discourses and practices consider most important.

We argue that this equivalence results in a notion of armed conflict that limits the understanding of violence. In turn, the violence of war, considered as a human activity, marginalizes forms of understanding war that go beyond the objectification of the environment, including the role of violence-via-environment. Following Tyner, we argue that violence should be historically situated, the result of practices and social relations. This allows us to understand how modes of violence are hierarchically organized, legitimized or obscured, and to pay attention to what becomes defined as violence and through what kinds of processes (Tyner 2016: 201). We argue that the framing of war as armed conflict produced a definition of violence that was legible within international legal frameworks, placing that definition within the realm of the human and excluding environmental practices of violence.

\section{Coca}

\section{The burning forest}

In February 2018, President Santos declared that the Chiribiquete National Park, located in the department of Guaviare, was to be expanded by 1.5 million hectares and turned into a UNESCO World

\footnotetext{
${ }^{8}$ This isn't to say that environmental destruction is not a discussion in the context of the Colombian war, though it is often limited to effects such as the explosion of oil pipelines by the guerrillas or the destruction in the forest left by military bombardments. For a discussion of land as resource in the conflict, see "El acceso a la tierra ha sido el eje del conflicto" (The access to land is the axis of the conflict", Revista Semana, November 252010 https://www.semana.com/nacion/articulo/el-acceso-tierra-ha-sido-eje-del-conflicto-armado/125048-3/ [accessed May 19 2021] and "La tierra, epicentro del conflicto armado en Colombia", Diario el Pais, December 212012 : https://elpais.com/internacional/2012/12/21/actualidad/1356128746_461292.html [accessed May 19 2021]
} 
Heritage site. It must surely have appeared a bad omen when, as Santos travelled to the inaugural ceremony held in the National Park, he flew over a sea of smoke. The forests of Amazonia were on fire.

The expansion of the national park was part of a multi-national biodiversity corridor - a proposal for a series of islands of preserved 'nature' that would extend from the Colombian Andes through southern Venezuela, ending on the Brazilian Atlantic coast (Figure 1). The original proposal came from Martin von Hildebrand, who established the Amazon Gaia Foundation. The idea was that the corridor (also called the Path of the Anaconda) would preserve a contiguous line of forest and habitats from the Andes to the Atlantic. At 130 million hectares, the corridor would be the largest ecological conservation project in the world. Santos proposed the corridor at the Paris Climate Summit in 2015 - in his words - a gesture from Colombia to keep 'the lungs of the earth' breathing a little longer. ${ }^{9}$ This corridor, however, would not only allow for the movement and circulation of those who dwell within those spaces, it would also enable - in Santos' vision - for an enhanced presence of the 'state'; in particular, of the military. President Santos explicitly highlighted this kind of militarized conservation as one of the advantages of the corridor, which would in turn keep out illicit practices like the cultivation of coca.

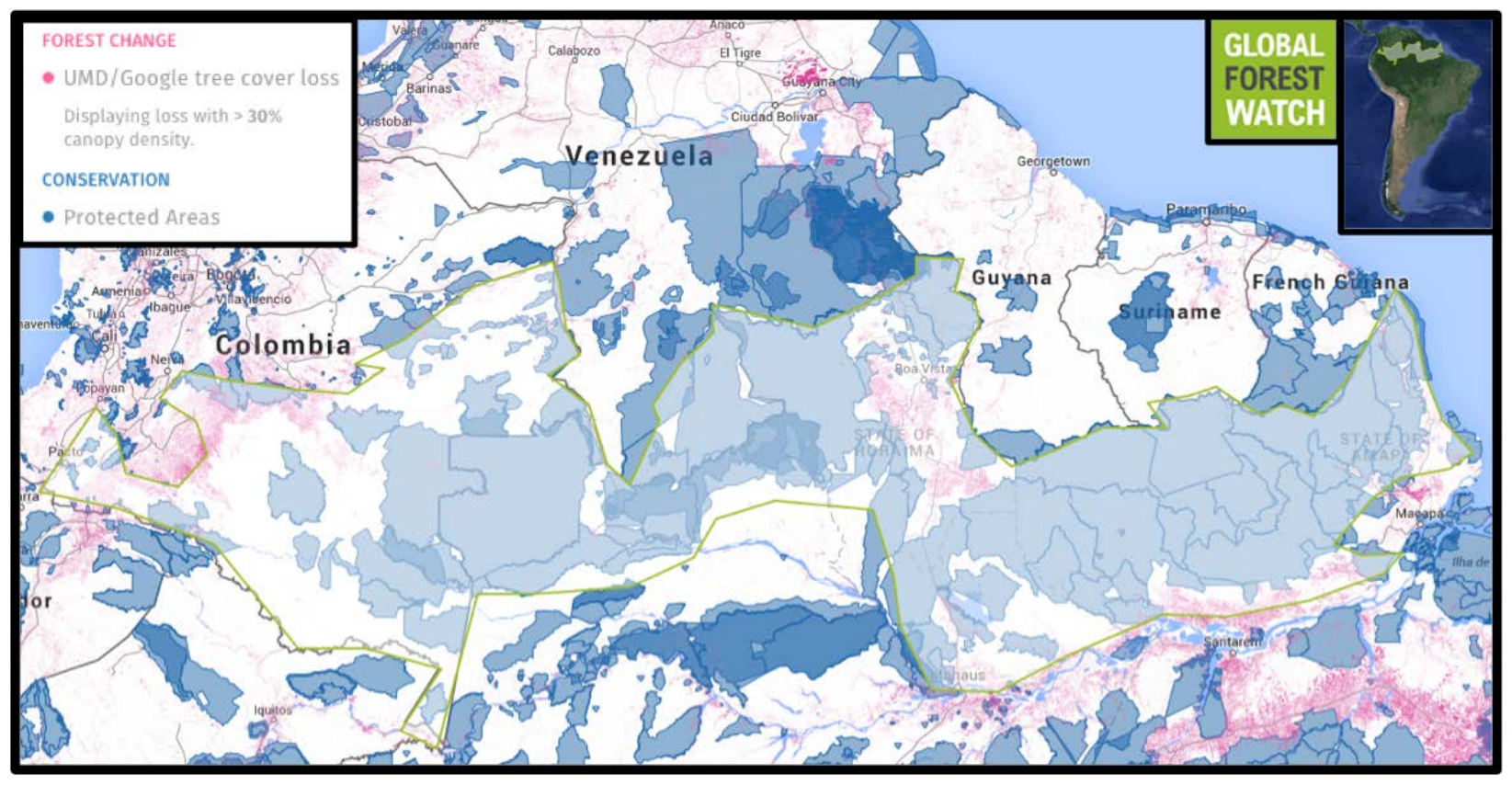

Figure 1: The proposed conservation corridor. Image source: Global Forest Watch

Chiribiquete is in an area known as the 'Andes-Amazon-transition belt', a biodiversity hotspot. The transitional belt also represents the area with the highest density of coca cultivation in the country (UNODC 2003-2013). It has been a traditional stronghold of the FARC and, as a result, the focus of many counterinsurgency campaigns. Santos' flight from Bogotá to the National Park in the post-peace agreement period of 2018 could therefore also be read as a symbolic journey: the state travelling to the previously unreachable, uncontrollable, chaotic center of the war; a gesture of the state enacting its sovereignty. Travelling to the heart of the wild, where the enemies of the state dwell under the forest cover.

\footnotetext{
${ }^{9}$ President Santos has been awarded both the Nobel Peace Prize (2016) and the Kew (Gardens) International Medal, for work protecting biodiversity (2017).
} 
That forest, however, was on fire. Not only was Amazonia burning, it was also being cut down. From the beginning of 2017, as the FARC left its territory in the transition belt and demobilized, the region began to experience some of the most intensive deforestation in the country.

It has been noted by multiple scholars that in Colombia, the dynamics of ecological destruction in relation to war and events of violence are not straightforward (Rodríguez et al. 2017). War cannot only be read as an ecocidal force, but also as one that preserves and even, in the case of the FARC, aims to actively conserve the forest (Ruiz Serna 2003).

In the lead-up to the signing of the accords, environmental groups were concerned that after the demobilization of the FARC much of the Colombian countryside would become vulnerable to extractive industries and - perhaps counterintuitively - to de-regulation upon entering the jurisdiction of the state. Falling out of what has been termed 'gunpoint conservation' (Álvarez 2003), these environments would be exposed to the dynamics of economies that operate on a scale often inaccessible to clandestine activities. 'Gunpoint conservation', as practiced by the FARC, amounted to a dual form of conservation that protected vast areas of land from large-scale development. On the one hand, the FARC had implemented a 'planned' form of conservation through various forms of environmental management they imposed on the territories they controlled (Ruiz Serna 2003). These environmental regulations significantly deterred territorial expansion of large-scale industry and small-scale land use. ${ }^{10}$ The other form of environmental management, 'unplanned' or unintended conservation, was most evident in the production of no-go zones that kept out large industries, developers, and multinational investors.

It is important to emphasize that the preservation of forest ecosystems also ensured a degree of camouflage crucial for the movement of materials, weapons, drugs, and people. Equating the forest with illegal practice and insurgency - a product of US Cold War counterinsurgency logic - made it permissible to destroy these environments in the name of national security. ${ }^{11}$ This was precisely the context in which aerial fumigation, as a method of eradication, was imposed on the country. ${ }^{12}$

In the months following the FARC's departure, the predictions and fears of environmentalists were realized: former FARC areas started to experience augmented deforestation almost immediately. ${ }^{13}$ As the demobilized guerrilla moved out, these territories opened to large-scale - legal - industries. Since the demobilization of the FARC, forest disturbance has increased by 187 per cent, impacting protected areas and the Amazon in general (Murillo-Sandoval et al. 2020). Under these conditions, it would seem that guerrilla law offered these environments more protection than subsequent Colombian environmental law. In this paradigm of competing forces of destruction and salvation, it is important to note that both realities have existed at once: war both simultaneously destroys and preserves nature.

As we outlined in the Introduction, coca cultivation has historically been scapegoated as the driver for the mass destruction of the forest. The very existence of the coca plant is posited as a direct threat to the most delicate and unique ecosystems of the country, especially the Amazon. Coca - and the campesinos who cultivate it - are blamed for deforestation and the expansion of what is called the 'agricultural frontier', the pollution of waterways via the disposal of chemicals used in the processing of coca leaves for cocaine, and the destruction of protected areas such as National Parks and reserves.

While these forms of destruction and pollution are present, they are used as a scapegoat, overshadowing another dynamic that is far more ecologically devastating. This is the production of enmity itself: both of coca and those who grow it. Here the idea of the enemy precludes and justifies practices of eradication as well as the processes of land transformation, development and extraction that precede it. The politics of eradication is

10 These included controls on forest clearing for agriculture and cattle ranching, hunting, timber extraction, fishing in mangroves and coca cultivation.

${ }^{11}$ Aerial fumigation was introduced in 1984, in the same moment when insurgency and narcotics were being fused together, as seen in the introduction of the term 'narcoguerrilla' coined by US Ambassador to Colombia, Lewis A. Tambs.

12 The method was officially authorized that same year, 1984, under the pressure of the United States.

13 There were many articles in the press and longer analyses written at the time: see for example Juanita Vélez and Natalia Arenas, 'El Impacto ambiental de la salida de las Farc', La Silla Vacia (5 July 2017) http://lasillavacia. com/historia/elimpacto- ambiental-de-la-salida-de- las-farc-61592, [accessed 27 March 2018]. 
a key component when understanding the ways in which the framing of coca as an enemy of the state has impacted the overall patterns of violence and destruction in the region. Through the criminalization of the coca plant, there is a simultaneous criminalization of those who cultivate it and the ecosystems in which it grows. Those condemned within this paradigm can be targeted for elimination; their very existence is considered a threat to the 'security' of the State.

\section{Framing the enemy: The plant that kills}

In the case of coca, the plant itself is treated as the source of poison: the poison that pollutes our ecosystems, just as it pollutes and poisons our bodies and minds. This ideology can be seen quite clearly in the government's advertisement campaign 'la mata que mata' ('the plant that kills'). ${ }^{14}$ In Spanish, the mirroring of language is very telling, rendering the plant itself (mata) synonymous with the act of killing (mata). An animated television advert broadcasted as part of the campaign featured a monstrous mata (which looks vaguely like marijuana) with evil yellow eyes, menacing teeth and a snake tongue. A hand comes and pulls the little menace out of the ground and the scene shifts to lightness. While this is happening, a young girl's voice tells us that, "if you stop cultivating the plants that kill, the land mines will disappear, the rivers of blood will dry up, the rain of bullets will cease and the dark nights will end, then the people can return to the countryside and grow more healthy crops." The equation of violence with the features of the natural world in the girl's speech gives us clues as to how the violence of the Colombian conflict has long been naturalized in the popular imagination. It is a violence that seems to originate from the Earth itself; the plants that kill have the power to animate the world they touch, transforming it into a landscape of death. In the video, the land, water and sky have been altered into a state of war, with the promise that, if the plant is eliminated, nature will return to a peaceful state.

According to this imaginary, the 'plants-that-kill' and the humans who consume, live, and die with them, are bound together, producing new categories of criminality. The plants and their cultivators, both framed together outside the nation-state, are the killers of the forest, and are thus the main threat to biodiversity. In this logic, killing this enemy would mean saving the forest. This logic, while not new, continues to play a significant role in the perpetuation and justification of eradication campaigns during a time of transitional justice.

Necropolitics emerges in the crux between the plant itself being transformed into the enemy that must be destroyed - the plant seen to be the anti-peace and the anti-future of the state - and the methods of violence designed to eliminate it. The territorialization determined through eradication, especially as it is embodied by aerial fumigation, produces what Mbembe calls 'death-worlds', whereby mass populations - human and nonhuman - are subjected to the status of the living-dead (Mbembe 2003, 40).

Over the decades, eradication has been conducted on two fronts, both from the sky and on the ground. While herbicidal eradication in Colombia can be traced back to the 1970s, the practice of aerial fumigation was formalized in 1994. ${ }^{15}$ When the US-funded 'Plan Colombia' was implemented in the early 2000s, counterinsurgency merged with anti-narcotics policy and the transitional belt was subjected to some of the most intensive eradication via aerial fumigation in the country. ${ }^{16}$

Eradication with the herbicide glyphosate has been a driving force of ecological destruction across the various environments of coca cultivation. ${ }^{17}$ The destructive nature of eradication operates on multiple levels. First, there is the initial devastation that occurs from the act itself. During aerial fumigation entire swathes of land - containing coca, subsistence crops, forest and homes, were sprayed often multiple times from planes

\footnotetext{
14 The campaign was initiated in 2010 by the Dirección Nacional de Estupefacientes (DNE - the National Narcotics Directorate) and included many propaganda advertisements such as this one: LA MATA QUE MATA NO CULTIVES https://www.youtube.com/watch?v=mvDz7n_1JvI [accessed January 1 2019].

151994 was the beginning of PECIG (Program of Eradication of Illicit Crops with Glyphosate)

${ }^{16}$ Plan Colombia, a multi-billion-dollar military and developmental aid package from the United States, was designed during the end of the Clinton administration in the United States in tandem with the Pastrana administration in Colombia.

17 For a report on this matter see Germán Andrés Quimbayo Ruiz (2008) Crops for illicit use and ecocide. Transnational Institute.
} 
flying at heights 100 times above the recommended application distance for the herbicide. ${ }^{18}$ Glyphosate is an indiscriminate killer of plant-life and its use in aerial fumigation had immense effects on the surrounding forest. Second, when the soil was rendered sterile from the herbicides, this would force farmers off their land, often displacing them deeper into forested areas. Third, abandoned land was often re-appropriated, and sometimes sold to large landowners who would pursue far more destructive industries, such as petroleum, palm oil, or cattle ranching.

Historically, aerial fumigations often correlated with an increased military presence on the ground. In most instances, there would be a military incursion preceding the fumigation. This was to 'securitize' the area since the guerrillas would often shoot at the planes. The fumigation planes were often accompanied by armed helicopters operated by the military. The presence of the military in turn led to confrontations and further escalations of violence between the army and the civilian population. Ground eradication, or manual eradication, involves a police task force often equipped with backpack tanks filled with herbicides; these task forces are also armed. Violence from police eradicators against cocaleros and campesinos is common and the peace agreement has not changed this. In October of 2017, for example, six campesinos were massacred by the anti-narcotics police in Tumaco during a protest against the manual eradication of their crops.

\section{Eradication as conservation}

In the Peace Accords a detailed plan was drawn up to address the issue of illicit crops called the National Comprehensive Crop Substitution Program, which outlined various mechanisms intended to curb their cultivation. The idea was to provide financial support through substitution programs to campesinos who were willing to self-eradicate their crops and transition to licit forms of agriculture. This strategy was a movement away from enforced eradication. However, when Ivan Duque, who largely opposed the peace process, was elected president in 2018, this ushered in another era of policies influenced by the far right, including a renewed emphasis on militarized eradication.

Despite the evidence that links eradication to territorial expansion and thus, deforestation, since assuming office the Duque administration has pushed for the reintroduction of aerial fumigations with glyphosate as part of its 'Future Path.' The 'Future Path' argues that coca is the main threat to biodiversity and conservation in the Amazon, describing deforestation as a 'national security problem.' The Economic Development Plan of 2018 called for an even greater military presence to enforce conservation. While in the context of coal mining we witness a form of militarization aimed at protecting resource extraction, under this plan the government created "Strategic Zones of Comprehensive Intervention" (ZEII), which are areas where the military and the police are responsible for protecting biodiversity, considering these territories as relevant for the interests of national security. ${ }^{19}$ The plan also called for the enforcement of licit agriculture via military and police interventions. These measures guarantee the continued criminalization of campesinos and the ecologies in which they cultivate, leaving these communities and their environments in a permanent condition of violence. Between 2016 and 2020, 95 clashes were recorded between campesinos, the ESMAD (riot police) and the army when resisting forced eradication. ${ }^{20}$

Duque developed this militarized vision of conservation further with 'Operación Artemisa', launched in April 2019, a military operation allegedly designed to stop deforestation. The operation's first mission was in Chiribiquete. This form of green militarization which underlies plans of conservation has a very specific aim.

\footnotetext{
${ }^{18}$ For an in-depth analysis on the misuse of the herbicide during the campaign, see ICJ 2008, Case concerning aerial herbicide spraying: Ecuador v. Colombia, Reply of Ecuador v. I (31 January 2011).

19 "The National Security Council will declare territories that are relevant to national security 'Strategic Zones of Integral Intervention' (ZEII); the protection of water, biodiversity and the environment, strategic assets of the nation, and those that are most affected by crime and illicit economies, in order to protect the population and guarantee unified, coordinated, interagency, sustained and integral action by the State. Such areas will be the subject of comprehensive intervention plans with a minimum duration of five years, to strengthen the social rule of law, and will be a priority for the provision of social services and reinforced measures to protect the civilian population." (Government of Colombia 2018)

20 See the database of the Observatory for the Restitution and Regulation of Agrarian Property Rights: https://www.observatoriodetierras.org/erradicacion-forzada-politica-quemata/?doing_wp_cron=1633882235.0942258834838867187500 [ accessed Dec. 27 2021]
} 
More conservation means more control of the territory and less room for the 'rivers of blood' and the plants that kill. Coca is not included in the future vision of a peaceful Amazon. After two years of the operation, human rights groups and legal teams denounced the disproportionate targeting by military and police forces of campesinos living on the borders and sometimes within natural reserves. ${ }^{21}$ The operation has left other more powerful large landowners, who are far more culpable for deforestation, unscathed. ${ }^{22}$ Green militarization is also not working for the forest. In 2020, 70 percent of the country's deforestation was concentrated in the Amazon (Figure 2). ${ }^{23}$

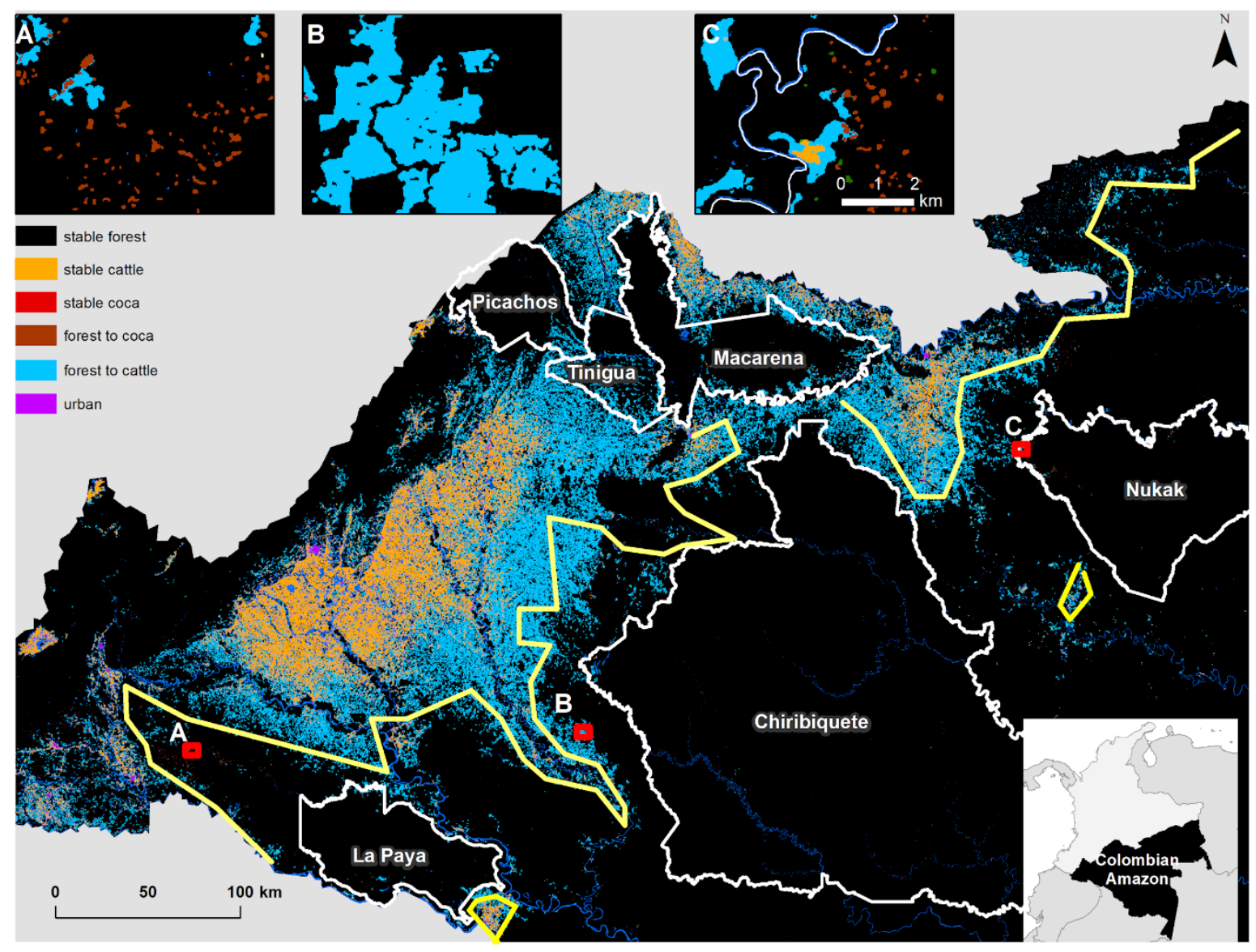

Figure 2: Expansion trends between 1987-2019 showing the dynamics of coca, pasture and forest. Everything inside protected areas (demarcated in white) and outside the yellow line is considered illegal. Image: Paulo Murillo-Sandoval 2020

The accelerated deforestation of the Amazon after the signing of the Peace Accords reveals that the forces of destruction at play in the Colombian selva are not only about illegality. It has been noted that deforestation is occurring as an act of speculation. The land that is cleared is not used for a specific purpose,

21 https://www.justiciaypazcolombia.com/organizaciones-rechazan-atropellos-de-la-fuerza-publica-a-campesinos-delparque-nacional-natural-tinigua [accessed Dec. 28 2021]

${ }^{22}$ https://www.elespectador.com/ambiente/que-tan-efectiva-ha-sido-la-intervencion-militar-para-detener-ladeforestacion-article [accessed Dec. 28 2021]

${ }^{23}$ https://es.mongabay.com/2021/07/crece-deforestacion-colombia-2020 [accessed Dec. 28 2021] 
but to increase its value for potential buyers. ${ }^{24}$ In Guaviare, Caquetá and Putumayo, this cleared land is used for cattle pastures, which are often an intermediary economic activity before the land is sold on. This kind of land clearing goes beyond the bounds of the coca economy. It has become evident through the work of Paulo Murillo-Sandoval (2020) for example, who shows that in the post-accord environment, clearing primary forest for cattle ranching has increased exponentially and is now pushing deeper into the Amazon watershed. Murillo Sandoval's remote sensing analysis (Figure 2), concludes that cattle play a more direct role than coca in forest conversion (the clearing of primary forests) and poses a more significant threat to biodiversity and conservation. Some of this conversion is legal, some is not, but the point is not to look at the separation of what practices fall in or outside the law, but rather the continuum between one another.

What we are witnessing today with this extreme form of destruction via deforestation is emblematic of a deeper relationship between so-called licit and illicit economies, representing, to a devastating degree, the extent to which licit economies depend on their illegal counterparts in order to expand and perpetuate themselves. Meanwhile, the criminalization of nonhuman life and its enforced eradication combined with military interventions sits within this continuum of destruction. This also calls into question what many conservationists are demanding in response to this devastating increase in deforestation, which is a greater 'state presence' in these areas. Under the conditions of increased militarization and eradication, what does a greater 'state presence' mean for the future of the Amazon? That answer could perhaps be best captured in the image of Santos flying over the burning forest and another plane which sprays poison over its ruins.

\section{Coal}

\section{Sedimented histories of death}

La Jagua de Ibírico, a town located in the department of Cesár, is the starting point of what is called "the mining corridor" (corridor minero). The corridor is an interconnected landscape in which coal circulates from seven open-pit mines in Cesár to the ports along the Caribbean before being shipped to Europe and the United States. The mining corridor is composed of four municipalities articulated around the coal extraction economy, its infrastructure and the administration of mines, jobs and towns.

La Jagua is the starting point of a tour through the corridor conducted by the mining union: SINTRAMINERGETICA in Cesár. We made this trip in November of 2017. The journey is carefully crafted, aimed to demonstrate the myriad of environmental, political and economic effects of coal mining in the region.

We were taken to El Hatillo, a village so close to a mine that the levels of pollution in the air, water and soil have made it impossible to live there (Figure 3). The condition became so dire that the Ministry of Environment and the Constitutional Court ordered the relocation of the village, an action that has yet to be realized. ${ }^{25}$ The tour included conversations with community leaders who explained how the coal dust blown from a coal train throughout the corridor has caused severe health issues and damaged their crops. We visited the houses of people living alongside the railway, who claimed that the vibrations of the train produced cracks in the walls of their homes. We passed through arid landscapes and heard stories of how these lands used to be green plots used for small-scale agriculture. Then there are the military posts, hidden from the public eye, which require extreme care, as remaining too long in their proximity is enough to raise suspicion.

Extractivist projects are often enforced through the combination of land grabbing, the intensification of counterinsurgency and the militarization of the landscape (Kikon 2019; Dunlap 2020; Seoane 2013; Engels and Dietz 2017). In this section, we examine the process of the imposition of coal through these three interrelated processes and show how they are related to the production of enmity through bio- and necropolitical practices, violence-via-environment, and finally the links that these practices have to conservation and militarization.

24 See for example: https://news.mongabay.com/2018/03/in-colombia-a-national-parks-expansion-announced-asdeforestation-progresses/

${ }^{25}$ https://verdadabierta.com/alerta-comunidad-de-el-hatillo-en-cesar-esta-en-riesgo [accessed Dec. 28 2021] 


\section{Managing life and death through coal}

Large-scale coal mining was introduced in the department of Cesár in the mid-1980s, when the U.S based company Drummond started its exploration in the region. Coal came with the promises of modernization, progress, connection to international markets and a constant flow of revenue. Huber and McCarthy consider that "industrial capitalism could be defined as a subterranean energy regime [for] most of its energy is extracted from under the ground" (2015, 656). This logic meant that the subterranean qualities of Cesár held the possibility of connecting what was understood as a backward agricultural region to the forefront of global capitalism.

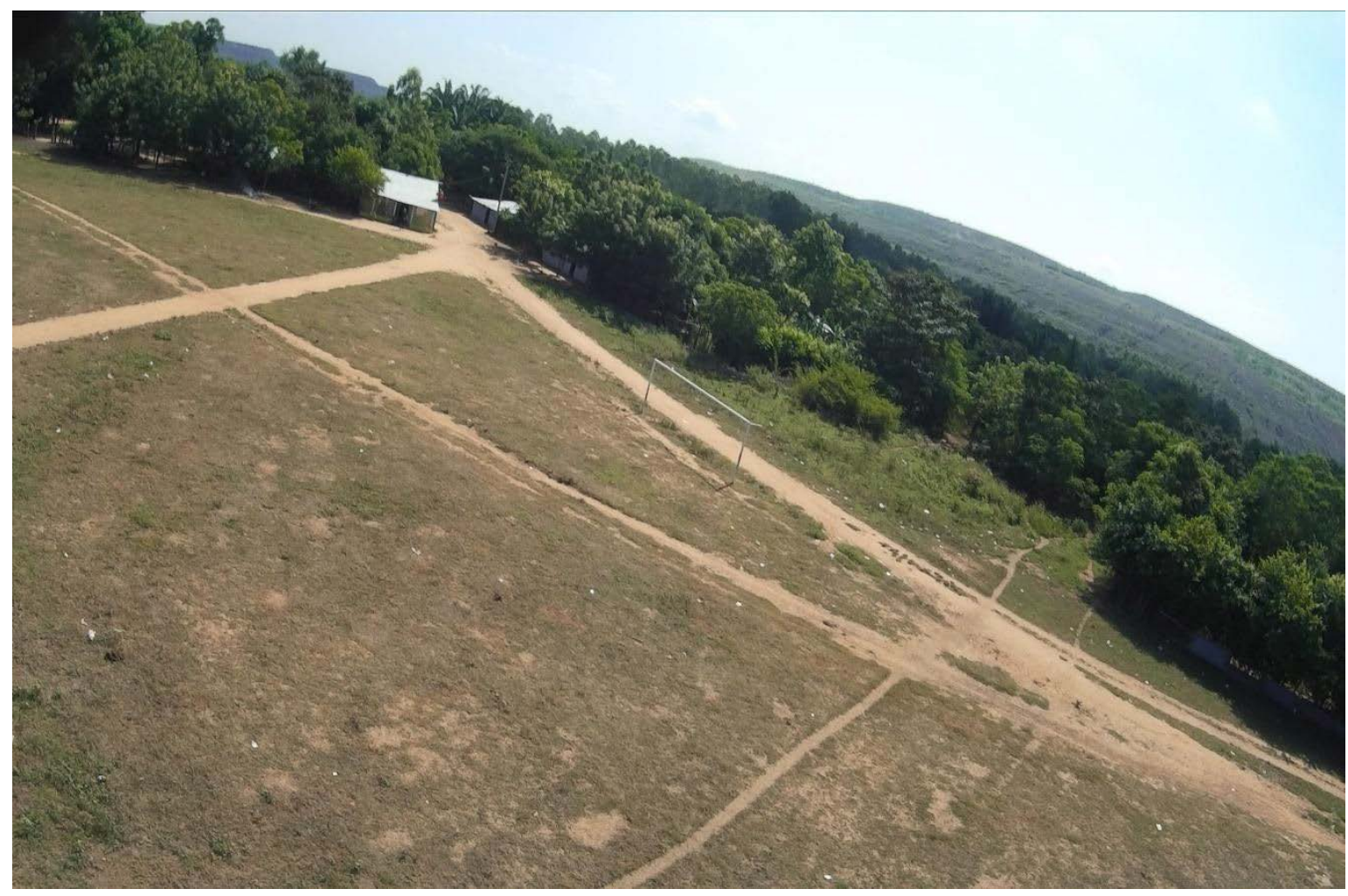

Figure 3: El Hatillo village and surrounding hills created by mining - as seen from a kite camera, 2017. Image by authors and the mining union

In Cesár, coal became that possibility but for the state and regional elites, because it was a way to bring into existence the ideas of modernity and civilization that were often opposed to agricultural relations and associated forms of the organization of life. As a renowned lawyer who has worked extensively in the area said to us during a conversation:

I don't think that coal just wants to destroy life. What it wants is to make certain lives go extinct in order to put others in place. Coal wants indigenous lives gone, peasants and unions gone, as well as their relations with nature. What they want is to impose the lives of elites and transnational corporations and extract all they can. They want to impose their life and destroy what opposes it. ${ }^{26}$

\footnotetext{
${ }^{26}$ Conversation in Bogota, May 2018.
} 
In the case of Cesár, the assertion of a sovereign power required rendering certain humans and their produced environments as enemies of the coal industry. The assemblages of coal extraction were deemed worthy of sovereign protection, as they provided a mode of existence that was valued more by the state. This reorganization of life demanded the destruction of existing socionatural arrangements and their material networks to impose those required by the coal industry, extending the notion of enmity beyond humans to environmental assemblages.

Until the late 1960s, the environment was organized around the use of nature for cattle ranching and cotton (CNMH 2016). Most of the cotton plantations were wiped out by disease. Coal emerged as an alternative for the modernization-industrialization of the region (Montoya-Dominguez 2018). From that moment, political organizations began to question the state's support for coal, big landowners and transnational investment, and its disregard for campesinos and land redistribution.

Criticism of government actions was taken to be a threat to the stability of the region. The escalation of war and counterinsurgency then created a direct link between guerrilla activity and opposition to the statesponsored extractivist project. At the same time, campesinos and civil society organizations were targeted by paramilitary groups. $^{27}$

It was in 1986 that the Colombian state declared itself "the public utility of mining at all of its stages" through a legal decree (Tierra Digna 2016). This status allowed the state to extend its legal control over mining, supposedly in the national interest. This privileged these subsurface resources over small-scale agricultural activities, and their relationship with nature on the surface. A state of exception prevailed, in which accountability, environmental regulation and protection of life were suspended to favor the coal industry.

Scholars have pointed to the importance of verticality in relation to fossil fuel and mining-related projects (Klinke 2019; Perrault 2013; Martin 2019). Geographies of production, use and the governance of resources occur above and below the Earth's surface (Weizman 2012; Elden 2013, Campbell 2018). The management of the subterranean became a chief concern of the state (Richarson \& Weszkalnys 2014). Over time, the surface of the Earth, on (and with) which campesinos operate was increasingly seen as outside the public interest. The coal industry required this disregard, devaluation and ultimate destruction of the existing entanglements of life in the tropical dry forest. Such entanglements were expendable and sacrificial.

A deep form of destruction emerged, with the objective of installing the coal industrial complex over and below the entire landscape. In Cesár, coal lies just beneath the surface and is spread throughout vast underground landscapes. The horizontal plane became as important as the vertical one. Open pit mines crack the earth open, digging into it, but they also expand themselves along a horizontal axis.

Amid an ongoing war, the full force of state counterinsurgency practices was brought to bear on campesinos, indigenous communities and workers' unions. Through a combination of illegal paramilitary groups, and investment in coal extraction and its protection via the national military, the industry expanded. The future was embodied in coal, paved roads, foreign investment, trains and revenues.

In the process of unearthing coal, there is a material displacement of all that is dug up in the process. The unearthed soil and rock are what remakes the landscape around the mine, reforming the land into a series of unnatural ridges, dug-out canals and mountains of waste. Mbembe explains that:

Colonial occupation itself was a matter of seizing, delimiting, and asserting control over a physical geographical area - of writing on the ground a new set of social and spatial relations. The writing of new spatial relations (territorialization) was, ultimately, tantamount to the production of boundaries and hierarchies, zones and enclaves; the subversion of existing property arrangements; the classification of people according to different categories; resource extraction; and, finally, the manufacturing of a large reservoir of cultural imaginaries. (Mbembe 2003, 2627)

27 By 2016, at least 2,841 victims were demanding the restitution of 195,000 hectares of land (CNMH 2016, 102). Given that "most municipalities coincide with the existence of currently valid mining titles" (CNMH 2016, 106), the correlation suggests that the coal industry is a driving force of displacement and land dispossession for peasant communities. 
Established relations between campesinos and their surficial agricultural livelihoods were obstacles to the future of the nation's progress. To access underground resources and achieve industrialization and development, humans and the surface environments on which they lived, as well as their practices, became enemy subjects.

\section{Militarization}

During our tour in November 2017, the specter of the military and the mines were always present yet unseen. We stopped on the side of the road for a few minutes and were shown a military post barely visible on a hilltop, through the vegetation. These posts are strategically located close to the mines. However, this proximity is entirely hidden from the public. Mines are also often concealed behind giant mounds of earth and spoil heaps, palm oil fields and barbed wire, rendering them invisible and thereby unknowable from the exterior.

Through their concealment in the overturned landscape, the relationship between the mines and the military posts is also lost in the rubble. On November 3rd, 2015, Ivan Cepeda, a left-wing senator who has struggled for decades to unveil the political ties of paramilitarism with Colombian elites, conducted a public hearing in which he linked the contracts made between mining corporations and the Colombian army to a renovated form of private security. These contracts resembled the past practices of paramilitaries, which created an armed infrastructure of security financed by different corporations. ${ }^{28}$ In the new form, army battalions were often created exclusively to protect one corporation, suggesting the privatization of the national army paid for by the Colombian public's taxes. ${ }^{29}$

There have been attempts by activists and politicians to access legal documents showing that the landscapes of coal extraction are defined by exception. They are sites where laws are suspended to make way for exceptional forms of exerting power. Based on the argument of "public utility" and the idea of insurgency as an ever-present threat, militarization and secrecy are justified by the state as necessary measures of control.

These rules also privilege tropes of conservation that in turn create enemies of those deemed as threats - as we also saw with coca (Devine 2014; Dwyers, Ingalls and Baird 2016; Woods and Naimark 2020; Ybarra 2016). In the Amazon, the forest is to be conserved: in Cesár, it is 'nature' as it relates to coal mining. In Cesár, the spaces of exception are not bounded by legal demarcations - as for example in National Parks - but by the infrastructure of coal extraction.

Within the mining corridor, where the protection of coal mining infrastructure means protecting the forms of life that coal produces, the state of exception is dispersed and uneven. It is not possible to create a homogenous space of exception along the mining corridor, as the mines form a patchwork landscape, and mining is forced to interact with towns and agricultural communities. There is a partial suspension of law (one that favors coal extraction) only in certain, and not necessarily contiguous areas. Fixed spaces, such as the mines and ports, enjoy an almost complete state of exception. Because of the constant threat of terrorist attacks, companies like Drummond strictly control any unauthorized presence inside their mines or in the surrounding area. Likewise, transporting coal is protected by the Colombian army.

The terrorist threat is easily activated when a particular activity is categorized as a risk to the mining industry. This includes not only stopping for a few minutes on the road - as we did - but also visiting towns, asking questions, taking photographs or making notes in public - as we also did. Open pit mines are special sites of exception to which the public has no access. As explained to us by several environmental activists, union members and lawyers, this creates forms of secrecy that allow the military and mines to operate in obscurity, as well as enabling paramilitary organization and surveillance.

\footnotetext{
${ }^{28}$ At least 1,229 contracts between infrastructural or extractive companies and the Colombian army, and twenty battalions specially designed to protect these industries since 1990 .

${ }^{29}$ The battalions are called Special Energy and Roads Battalions (SERB) Battallones Especiales Energéticos y viales. At least one of these battalions was dedicated explicitly to the protection of Drummond.
} 
Inside the concealed mining sites, Drummond has created special recovery areas set aside as natural reserves to comply with environmental regulations. Activists, environmental organizations and scholars do not have access to these sites; however, Drummond started publishing yearly reports of their activities in 2010, which include their supposed accomplishments in the process of reforestation.

In 2019 Drummond released 100 turtles, a snake, six guacamayas (parrot, Rhynchopsitta pachyrhyncha) and twenty iguanas in their conservation areas. Regional environmental institutions chose Drummond because their "biosensory and rehabilitated areas are strengthened and continually protected. In that way, we guarantee that these species can fulfill their biological purpose and reproduce". ${ }^{30}$ The conservation claim made here is articulated around the potential threat that those people surrounding the mine pose. The enemy, from this point of view, lives within the mining corridor and around the mines, embodied in the incapacity of peasants and village inhabitants to protect the environment. As the argument goes, the private spaces of conservation created by Drummond guarantee environment survival.

And yet, in 2013, Drummond dumped at least 600 tons of coal into the sea, and the inhabitants living throughout the mining corridor describe high levels of pollution, the destruction of crops and the progressive degradation of the environment. ${ }^{31}$ As Davies (2018) suggests, the destruction of the environment is akin to what Mbembe defines as a 'state of injury', in which humans are kept alive but 'let die' in a progressive manner with little to no accountability. To this argument we add that through degrees of exception present in the mining corridor, forms of human and nonhuman life experience a state of injury that favors the modes of life existing inside the mines, while effectively leaving for dead those wounded in the exterior world. Those left to die are the forms of life considered to be antagonistic to coal extraction. Despite this, the idea that Drummond has established conservation zones inside their mines reinforces the notion that the securitization supported by state armed forces leads to regulated environmental practices, and the flourishing of forms of life supported by coal.

In the contracts signed between Drummond and the Colombian army, the link established between the two parties is framed, first and foremost, in terms of the public utility of the coal industry in all its phases; secondly, in terms of the duty of the Colombian army to uphold its responsibility to protect and secure that which is considered to be of national interest; and thirdly, in terms of the proper management and protection of the environment. Velez-Torres (2018) has shown that since 2003 the Colombian government has privileged securitization as a means "to win the complete control of the territory by the State to ensure the full imperium of law, governability and thus strengthening the rule of law" (Ministerio de Defensa Nacional, 2003: 9 in VelezTorres 2018: 73). As argued by Velez-Torres, since 2011, "two main forces were seen to threaten national security: one, threats in which illegal actors and environmental catastrophes seem to play an equivalent role; and two, counter-threats, divided between government-related powers (executive, legislative, and judicial) and 'others' (civil society and private industry)." As is also evident in the case of the Amazon, "military control is still the government's main mechanism for granting security." (Velez-Torres 2018: 74). ${ }^{32}$

A common question surrounding the mines is what could occur after coal ceases to be profitable. The imperative to phase out coal in European countries has led to concern in Colombia. As international voices around the effects of coal and $\mathrm{CO}_{2}$ emissions get louder, it becomes more important for companies like Drummond to show that they have a recovery plan for the devastated environments around the mines. Arguably, this is one of the reasons that led to the creation of conservation zones inside Drummond's mine sites.

One of the main findings of environmental activists has been the lack of clear understanding regarding what existed - ecologically speaking - before large-scale mining took over, or what they call an ecological 'baseline' (Tierra Digna 2015). For this reason, it is almost impossible to measure the extent of mining destruction through standardized scientific procedures. This lack of historical data combined with the secrecy surrounding mine sites, makes it difficult to assess the efficacy of Drummond's conservation efforts. The

\footnotetext{
${ }^{30}$ https://radiomagdalena1420am.com/areas-de-conservacion-de-drummond-ltd-acogieron-a-127-ejemplares-de-distintasespecies-de-fauna-silvestre [archived here]

${ }^{31}$ https://www.semana.com/nacion/articulo/vertimentos-de-carbon-en-santa-marta-juez-falla-en-favor-dedrummond/596983 [accessed Dec. 28 2021]

32 This can be observed in the Plan de Consolidación Territorial (Plan of Territorial Consolidation).
} 
company argues that it is following the national requirements for sustainability. However, their practices of measuring 'sustainability' represent the only assessment of environmental recovery and conservation in the region. Given this situation, there are no definitive answers about how their efforts may be ecologically sustainable or contribute to conservation.

As we stated previously, by maintaining coal extraction within the definition of public utility, the mineral remains a priority that must be protected for the very stability of the nation (Koch and Perrault 2019; Domjan and Stone 2010; Kohl and Farthing 2012). The industry remains a major part of the project of national development and participation in the global economy, despite international efforts to transition away from fossil fuels. Today, coal is portrayed as a legal and regulated industry, supporting the country in its post-war transition.

Responsible mining is depicted as involving conservation efforts. These are useful for countering the critics of mining pollution, its decades of environmental destruction, and the modalities of armed violence deployed against opposition activists and communities. Given that the history of socionatural violence used to install coal mining in the region is now in the past, it is easier for the industry to argue for the importance of its current biopolitical organization of the landscape and conditions of violence. Of course this violence-viaenvironment is still denounced by scholars, NGOs and social movements. In their eyes, the military is not protecting an industry that could bring security and peace to the nation, but instead is securing the country's demise by managing the slow death of its environment.

Our tour through the mining corridor had the objective of showing the interconnected modalities of violence that escape the gaze of transitional justice, to the extent that violence-via-environment is not seen as a direct effect of the armed conflict. The mining union (SINTRAMINERGETICA) exposes the limits of violence and alienation of humans from nature. Union activists highlight the layered paradox of transitional justice: coal is defined as a stable project of liberal democracy based on the regulated use of nature as a resource. Through this representation of a stable, peaceful future, coal's violent past and present continues to exist outside the frameworks of transitional justice. However, the industry requires the nation to direct its military resources towards its protection, while coal mining degrades and endangers the future of human and non-human life. The question for the union and other opposition forces is also a paradox for transitional justice: what kind of future might exist after war, when the very possibility of life is put in question?

\section{Conclusion}

Colombia experiences the vivid coexistence of war with the aspiration of peace. In the counterpoint of coca and coal, plants and minerals embody the historical processes that define what modes of life are deemed worthy of living and dying in an imagined future of peace and stability. The tandem of extinction-conservation is explicitly tied to what the Colombian state defines as valuable. Coal is situated as legitimate and legal, projecting the possibilities of specific modes of life that the state has considered as desired objects for a long time. Coca, on the other hand, falls within the space of the outlaw, and as such embodies a threat that goes to the core of the organization of the nation state (Martin 2019). In the case of coal, military infrastructure has developed around the industry to protect resource extraction, which is framed as a matter of national interest. In the case of coca, the military is called upon to supposedly protect the biodiversity (also of national interest) that coca threatens.

The militarization of nature is organized around these concerns for the future of the nation. However, unlike most analyses of war and its violence, we argue that more than human beings should be considered in in our analysis. Enmity, from our point of view, cannot be restricted to an ontological realm, in this case that of the human. Indeed, we consider that expanding enmity to the natural environment not only forces us to rethink the human/nature dualism, but also implies a re-evaluation of violence and the political. In this connection, the militarization of the environment does not occur only as the imposition of human will over a passive nature, but the environment is a mode and mechanism of violence, or what we call violence-viaenvironment.

In both cases, this militarization leads to further environmental destruction and the escalation of violence. Nevertheless, there are certain. forms of nature that are considered worthy of conservation, while 
others are placed at the center of state policies predicated on their extinction, such as the eradication of coca, or the lifeworlds of those opposing coal mining. In that sense, war and conflict simultaneously destroy and preserve the environment. The interplay of conservation and extinction in war is closely related to the formations of enmity and the modalities of violence at play. Aerial fumigation as eradication is a form of violence that operates environmentally, weaponizing nature's pathways - the air, the waterways, and the vascular system of the plant (Martin 2019). If this is not given full consideration, then the violence of war in transitional justice will remain obscure. In the case of coal, we see a clear example of how the State's economic model has augmented the bounds of political violence throughout the war to the extent that mass ecological destruction - and indeed forms of extinction - should also be considered as political.

In present circumstances, if the connections between economic development and political violence are ignored and go unchallenged, they will continue to perpetuate. We argue that in this transitional moment the most crucial task is to articulate the deep connections between the political and environmental, and the continued production of violence.

\section{Bibliography}

Agamben, G. (1998). Homo Sacer: Sovereign power and bare life. Stanford University Press.

Álvarez M. D. (2003). Forest in the time of violence: conservation implications of the Colombian war. Journal of Sustainable Forestry, 16: 47-68.

Annecke, W. \& Masubelele, M. (2016). A review of the impact of militarization: The case of rhino poaching in Kruger National Park, South Africa. Conservation and Society 14(3): 195-204.

Bellamy Foster, J. (2000) Marx's ecology: Materialism and nature. NYU Press.

Bernal, V. \& Grewal, I. (Eds.). (2014). Theorizing NGOs: States, feminisms, and neoliberalism. Duke University Press.

Bhan, M. \& Trisal, N. (2017). Fluid landscapes, sovereign nature: Conservation and counterinsurgency in Indian-Controlled Kashmir. Critique of Anthropology 37(1): 67-92.

Bowsher, J. (2018). 'Omnus et Singulatim': Establishing the relationship between transitional justice and neoliberalism. Law and Critique 29(1): 83-106.

Bradley, M. (2013). International humanitarian law, non-state armed groups and the international committee of the Red Cross in Colombia. Journal of International Humanitarian Legal Studies 4(1): 108-134.

Büscher, B. \& Fletcher, R. (2018). Under pressure: Conceptualizing political ecologies of green wars. Conservation and Society 16(2): 105-113.

Campbell, E. (2019). Three-dimensional security: Layers, spheres, volumes, milieus. Political Geography, 69, $10-21$

Castillejo, A. (2017). Introducción: Dialécticas de la fractura y la continuidad: elementos para una lectura crítica de las transiciones. In Castillejo, A. (Ed.). La ilusión de la justicia transicional: Perspectivas críticas desde América Latina y Sudáfrica. (pp.1-56). Universidad de los Andes, Colombia.

CNMH. (2016). La maldita tierra: Guerrillas, paramilitares, mineras y conflicto armado en el Departamento Del Cesár. Centro Nacional de Memoria Histórica.

Conca, K., Carius, A. \& Dabelko G. D. (2005). Building peace through environmental cooperation. In State of the World 2005 (pp. 144-157). Worldwatch Institute.

Davies, T. (2018). Toxic space and time: Slow violence, necropolitics, and petrochemical pollution. Annals of the American Association of Geographers, 1537-1553. https://doi.org/10.1080/24694452.2018.1470924

Devine, J. (2014). Counterinsurgency ecotourism in Guatemala's Maya biosphere reserve. Environment and Planning D: Society and Space, 32(6), 984-1001.

Domjan, P. \& Stone, M. (2010). A comparative study of resource nationalism in Russia and Kazakhstan 20042008. Europe-Asia Studies, 62(1), 35-62. 
Dunlap, A. (2020). Wind, coal, and copper: the politics of land grabbing, counterinsurgency, and the social engineering of extraction. Globalizations 17(4): 661-682.

Dutta, A. (2020). Forest becomes frontline: Conservation and counter-insurgency in a space of violent conflict in Assam, Northeast India. Political Geography 77: 102117. https://doi.org/10.1016/j.polgeo.2019.102117

Dwyer, M. B., Ingalls, M. L \& Baird, I. G. (2016). The security exception: development and militarization in Laos's protected areas. Geoforum, 69, 207-217.

Engels, B. \& Dietz, K. (Eds.) (2017). Contested extractivism, society and the state: Struggles over mining and land. Springer.

Elden, S. (2013). Secure the volume: Vertical geopolitics and the depth of power. Political Geography, 34, 3551.

Fletcher, R. (2018). License to kill: Contesting the legitimacy of green violence. Conservation and Society 16(2): 147-156.

Foucault, M (2003). Society must be defended: lectures at the College de France, 1975-76. Picador.

Grandin, G. (2011). Who is Rigoberta Menchú? Verso.

Hamblin, J. (2013). Arming Mother Nature: The birth of catastrophic environmentalism. Oxford University Press.

Human Rights Watch. (1998). War without quarter: Colombia and international humanitarian law. Human Rights Watch.

Huber, M. \& McCarthy, J. (2017). Beyond the subterranean energy regime? Fuel, land use and the production of space. Transactions of the Institute of British Geographers 42(4): 655-668.

ICJ. (2008). Case concerning aerial herbicide spraying: Ecuador v. Colombia, Reply of Ecuador v. I (31 January 2011).

Ide, T. (2019). The impact of environmental cooperation on peacemaking: Definitions, mechanisms, and empirical evidence. International Studies Review 21(3), 327-346. https://doi.org/10.1093/isr/viy014

Kikon, D. (2019). Living with oil and coal: Resource politics and militarization in Northeast India. University of Washington Press.

Klinke, I. (2019). On the history of a subterranean geopolitics. Geoforum, 127, 356-363.

Koch, N. \& Perreault, T. (2019). Resource nationalism. Progress in Human Geography, 43(4), 611-631.

Kohl, B. \& Farthing, L. (2012). Material constraints to popular imaginaries: The extractive economy and resource nationalism in Bolivia. Political Geography, 31(4), 225-235.

Lunstrum, E. (2014). Green militarization: Anti-poaching efforts and the spatial contours of Kruger National Park. Annals of the Association of American Geographers, 104(4), 816-832. https://doi.org/10.1080/00045608.2014.912545

Lunstrum, E. (2015). Conservation meets militarization in Kruger National Park: Historical encounters and complex legacies. Conservation and Society 13(4), 356-369.

Marijnen, E. (2017). The 'green militarization' of development aid: The European Commission and the Virunga National Park, DR Congo. Third World Quarterly 38(7): 1566-1582.

Martin, H. J. M. (2016). How to make peace with the forest: Development and war in Colombia.8_Open Democracy https://www. opendemocracy.net/ hannah-meszaros-martin/ how-to-make-peace-withforest-development-and- war-in-colombia [accessed 27 Dec 2021].

Martin, H. J. M. (2019). The Outlawed Earth: Spectrums of violence, the visible and the politics of Violencia Ambiental. Doctoral Thesis, Goldsmiths College, University of London. https://doi.org/10.25602/GOLD.00027655

Matthew, R., Brown O. \& Jensen, D. (2009). From conflict to peacebuilding: The role of natural resources and the environment. UNEP/Earthprint.

Mbembe, A. (2003). Necropolitics, Public Culture, 15(1), 11-40. 
Mbembe, A. (2019). Necropolitics. Duke University Press.

Montoya-Domínguez, E. (2018). La extracción de carbón en el centro del Cesar, Colombia: apuntes para la comprensión del conflicto ambiental. Gestión y Ambiente, 21(2Supl), 62-73. https://doi.org/10.15446/ga.v21n2supl.77836

Moore, J. (2015). Capitalism in the Web of Life: Ecology and the accumulation of capital. Verso.

Murillo-Sandoval, P. et al. (2020). The end of gunpoint conservation: forest disturbance after the Colombian peace agreement. Environmental Research Letters. 15, 034033. https://doi.org/10.1088/1748$\underline{9326 / a b 6 a e 3}$

Murillo-Sandoval, P. et al. In review, 2021. The post-conflict expansion of coca farming and illicit cattle ranching in the Colombian Amazon. Proceedings of the National Academy of Sciences.

Ortiz, F. (1995). Cuban counterpoint, tobacco and sugar. Duke University Press.

Peluso, N. \& Vandergeest, P. (2011). Political ecologies of war and forests: Counterinsurgencies and the making of national natures. Annals of the Association of American Geographers 101(3), 587-608.

Perreault, T. (2013). Nature and nation: Hydrocarbons, governance, and the territorial logics of "resource nationalism" in Bolivia. In Bebbington A.J. \& Bury, J. (Ed). Subterranean struggles: New dynamics of mining, oil, and gas in Latin America (pp. 67-90). University of Texas Press.

Ramírez, M. (2011). Between the guerillas and the state: the Cocalero Movement, citizenship and identity in the Colombian Amazon Duke University Press.

Richardson, T. \& Weszkalnys, G. (2014). Introduction: Resource materialities. Anthropological Quarterly 87(1): 5-30. https://doi.org/10.1353/anq.2014.0007

Rodríguez, C., Rodríguez, D. \& Durán, H. (2017). La Paz ambiental: Retos y propuestas para el post acuerdo. DeJusticia.

Rothberg, M. (2012). Progress, progression, procession: William Kentridge and the narratology of transitional justice. Narrative 20(1): 1-24.

Ruiz-Serna, D. (2003). Campesinos entre la selva, invasores de reservas. Tabula Rasa. 1, $183-210$. https://doi.org/10.25058/20112742.193

Seoane, J. (2013). Modelo extractivo y acumulación por despojo. In Seone J., Taddel E. \& Algranati C. (Eds.). Extractivismo, despojo y crisis climática (pp. 21-40). Ediciones Herramienta.

Tierra Digna, et al. (2015). El Carbón de Colombia: ¿Quién Gana?¿Quién Pierde. Tierra Digna.

Quimbayo Ruiz, G. A. (2008). Crops for illicit use and ecocide. Transnational Institute.

Tyner, J. (2016). Violence in capitalism: Devaluing life in an age of responsibility. University of Nebraska Press.

United Nations (2003-2015). Annual Coca Cultivation Survey. UNODC. https://www.unodc.org/unodc/en/crop-monitoring/index.html?tag=Colombia

Valencia Villa, A. (1991). La humanización de la guerra: Derecho internacional humanitario y conflicto armado en Colombia. Ediciones UniAndes.

Vélez-Torres, I. (2014). Governmental extractivism in Colombia: Legislation, securitization and the local settings of mining control. Political Geography, 38, 68-78.

Weizman, E. (2012). Hollow land: Israel's architecture of occupation. Verso.

Woods, K. M. \& Naimark, J. (2020). Conservation as counterinsurgency: A case of ceasefire in a rebel forest in southeast Myanmar. Political Geography, 83, 102251. https://doi.org/10.1016/j.polgeo.2020.102251

Ybarra, M. (2016). "Blind passes" and the production of green security through violence on the Guatemalan border. Geoforum, 69, 194-206. 